\title{
CD8 Expressing T Cell Count
}

National Cancer Institute

\section{Source}

National Cancer Institute. CD8 Expressing T Cell Count. NCI Thesaurus. Code C74609.

The determination of the number of CD8 expressing T cells present in a sample. 